\title{
Demokrasi Dan Pembangunan Kesehatan
}

Setiap tahap dalam fase demokratisasi menghasilkan bentuk baru akomodasi persoalan publik. Begitu pula di sektor kesehatan, tidak terkecuali. Formulasinya sederhana, demokrasi berjalan linier dengan akomodasi kepentingan publik.bagaimana upaya membangun program kesejahteraan dimulai dengan agenda demokrasi. Persoalan publik, yang termuat dalam ranah kebijakan sesungguhnya terkait dengan hal-hal politik.Keterbukaan ruang politik, membuat agenda dan partisipasi publik dimungkinkan. Sementara itu, pada posisi yang sebaliknya, transaksi gelap di panggung politik, hanya akan menghasilkan jarak terpisah antara kepentingan publik dari pengambil keputusan. Kerangka oligarki politik yang menguat, mengabaikan serta meninggalkan aspirasi publik di bagian akhir. Bentuk tinjauan Aspinall pada literatur tersebut, memfokuskan diri pada pembangunan sistem kesehatan nasional. Salah satu tujuan yang hendak dicapai melalui momentum kemerdekaan adalah mengantarkan kesejahteraan, dengan upaya melindungi segenap warga negara. Sehingga usaha pembangunan dalam mengisi kemerdekaan, ditujukan untuk memastikan distribusi keadilan dan kemakmuran. Selama ini, mekanisme pembangunan, yang mengambil model trickle down effect hanya menyisakan rembesan serta tetesan ke tingkat publik, sebagian besarnya tersumbat di bottleneck mesin birokrasi. Selaras dengan pengamatan Aspinall, maka demokratisasi menjadi sarana bagi pencapaian tujuan agenda kesejahteraan, termasuk capaian kesehatan pada perjalanannya, Sistem Kesehatan Nasional (SKN) mengambil bentuk yang dinamis serta berubah sejalan dengan arah demokrasi. Pasca kemerdekaan, pembangunan sistem kesehatan berlangsung dengan model yang sentralistik. Pusat-pusat kesehatan dibangun melalui instrumen negara, jejaring pusat kesehatan masyarakat dirumuskan dengan konsep upaya kesehatan publik.

Di tahap awal, fokus penyelesaian masalah kesehatan ditujukan pada problem kesehatan dasar, khususnya berbagai penyakit infeksi menular yang terjadi. Termasuk melakukan edukasi serta promosi kesehatan publik yang terintegrasi dalam sistem pendidikan, dengan memperkenalkan konsep gizi seimbang empat sehat lima sempurna. Penguatan sarana dan prasarana pendukung dari sektor kesehatan, termasuk mencetak para pengabdi bagi pelayanan kesehatan, dirumuskan sebagai bagian yang tidak terpisahkan atas semangat kemandirian dalam mengurus persoalan domestik yang bebas dari intervensi kepentingan antar blok dunia saat itu.Peralihan politik dari Orde Lama ke Orde Baru, yang kemudian pada akhirnya mampu mewujudkan konsep Pusat Kesehatan Masyarakat -Puskesmas yang telah digagas sebelumnya. Termasuk berbagai program baru, semisal pelaksanaan konsep keluarga ideal, melalui Keluarga Berencana. Pengendalian populasi, merupakan sarana dalam melakukan kontrol publik.

Ketika transisi kritis Orde Baru, mewujud menjadi Orde Reformasi, maka gagasan kepentingan publik untuk perluasan akses kesehatan publik menjadi titik tekan yang penting. Realitas sosial akan sulitnya publik untuk memperoleh layanan dari fasilitas kesehatan, semakin disadari terjadi. Selain itu, kebutuhan akan peningkatan kualitas kesehatan publik, menjadi suatu standar kehidupan yang baru. Melalui fase demokratisasi, mimpi tentang negara kesejahteraan dihembuskan. Pembentukan peraturan mengenai Sistem Jaminan Sosial Nasional -SJSN pada akhirnya terjadi tahun 2004. Gagasan tentang kesamaan hak untuk mendapatkan perlindungan publik, melalui bentuk jaminan sosial di bidang kesehatan, semakin dimatangkan dengan Undang-Undang Badan Penyelenggara sosial - BPJS 2011

\section{$>$ Pengaruh Dukungan Sosial Terhadap Kesehatan}

Zeela Karina, Muhammad Ali Sodik

OSF Preprints, 2018 
Dalam beberapa riset menjukkan bahwa dukungan sosial diyakini bisa menjadi alat bantu atau penun jang untuk meningkatkan derajat kesehatan sesorang. Hal ini dikarenakan dengan adanya dukungan sosial yang baik maka akan menciptakan sebuah lingkungan yang baik pula. Lingkungan yang baik kana memberikan rasa nyaman yang membuat sesorang merasa dikasih sayangi dan dicintai. Sehingga mampu membentuk suasana emosi yang baik, dan membuat orang tersebut bahagia selalu. Seperti yang sudah banyak dijelaskan dari berbagai sumber,, bahwa banyak penyakit muncul akibat stress atau keadaan emosional yang kurang baik. Oleh karena itu, perlu dipelajari dan dipahami lagi mengenai dukungan sosial lebih dalam lagi, agar mampu untuk menjadi alat bantu meningkatkan derajat kesehatan seseorang. 